\title{
Who defines the narrative of a crisis? The case of an Estonian online boycott campaign against an international supermarket chain
}

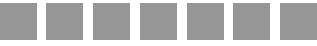 \\ Päivi Tampere \\ TALLIN N UNIVERSITY, ESTONIA \\ Kaja Tampere \\ TALLIN N UNIVERSITY, ESTONIA \\ Scott Abel \\ TALLIN N UNIVERSITY, ESTONIA
}

DOI: 10.19195/1899-5101.9.1(16).4

\begin{abstract}
This study examines the impact of social media activism in the form of a boycott case through the analysis of online and mass media news articles. The article reviews a conflict between a supermarket chain and its Estonian customers in April 2010, and focuses on definition hegemony (the process by which the crisis is defined), the reaction of journalists and consumers to the case, and its impact on a company's crisis communication. It examines the role of social media in formenting a crisis and keeping it active. The analysis of social media and mass media texts, as well as press releases, suggest that citizens have power over corporations because of their ability to raise questions, be critical of company behavior, and in defining the crisis narrative. The findings indicate that who is able to define the crisis can significantly affect its course.
\end{abstract}

KEYWORDS: crisis communication, social media, boycott, media relations, issues management, definition hegemony.

\section{INTRODUCTION}

Rimi Baltic, an international supermarket and retail chain headquartered in Riga, Latvia, and a subsidiary of the Swedish retailing group ICA AB of Sweden, faced an online boycott of its stores in Estonia after a media crisis developed over a change in its meat-selling policies in 2010. The Estonian branch of Rimi Baltic, which manages more than 80 stores in the country (Rimi Baltic, 2015) announced in a press release that it would not sell Estonian-produced meat under the Rimi brand. This release precipitated a strong reaction among consumers in Estonia, forcing the company to back down from its decision three days later. 
A crisis for an organization can be a serious threat; it can damage its reputation, and alter how stakeholders - individuals or groups that can affect or be affected by its actions, objectives or policies - perceive and relate to it. It can, as well, pose an existential financial hazard (Coombs, 2007). A wide range of stakeholders, from community members, employees, customers, suppliers and stockholders, can be seriously affected by an organization in a crisis mode. The possibility of an organizations' reputation - the aggregate evaluation the stockholders make on how well it can meet stakeholder expectations - being damaged can increase dramatically, which could alter how its stakeholders deal with it in the future (Coombs, 2007, p. 165).

The internet now can play a critical role in how a crisis unfolds. Social media platforms, or sub-arenas (Coombs and Holladay, 2014), such as Facebook, Twitter, Pinterest, blogs, and discussion forums, offer a wide variety of technical tools for self-expression or mass communication originated by individuals. Communication technology has also enabled public discussion and citizen participation. (Cheng et al., 2014).

Social media is increasingly a breeding ground for crises (Pang et al., 2014), altering the communication process from a sender-receiver relationship that informs receivers to a series of dialogues that is dominated by an information-sharing process (Capozzi \& Zipfel, 2012). Individuals and groups have increasing access to information and, at least potentially, the possibility to publish their opinions without filters, bypassing the mass media's traditional role as a gatekeeper (Conway et al., 2007). Crises can also develop if, like Coombs and Holladay (2012) argue, they are badly managed by a targeted organization. For example, unsatisfied stakeholders can use social media to get attention (Haigh \& Wigley, 2015) and can challenge organizational decisions or initiate collective actions (Shirky, 2011) through boycotts, campaigns, and online demonstrations. Siah et al. (2010) call this aspect of social media "a double-edged sword", as stakeholders can initiate issues that turn into crises, if they perceive an organization's actions as unethical, illegitimate, or otherwise violating their interests.

The field of crisis communication, however, does not know enough about the role social media, an increasing prominent component, plays in the conflict between organizations and their stakeholders in a time of crisis (Pang et al., 2014) and how stakeholders can use social networks to challenge the legitimacy of organization's decisions with the help of mass media. Therefore, it is the intention of this article, using the case of the Rimi Baltic boycott in Estonia, to discuss this nexus of social media, mass media and crisis communication.

\section{DIFFERENT CRISIS TYPES AND PERCEPTION OF RESPONSIBILITY}

Crises can be divided into two categories; organizational crises and disasters. Organizational crises can be further divided into two categories of traditional and 
social media crises (Coombs, 2014). Disasters are large-scale and require multiauthority response (Ulmer et al., 2011), however they also spawn organizational crises (Coombs, 2014). Organizational crises are usually defined as:

[...] unpredictable events that can disrupt an organization's operations, threaten to damage organisational reputations. (Coombs \& Holladay, 2002, p. 166)

Crises can especially seriously harm an organization's reputation, if they are badly managed and communication is insufficient (Ulmer et al., 2011).

Social media crises are mostly reputational, originating in social media or spreading there. Whereas traditional crises primarily concern public safety and welfare, social media crises concern reputation (Coombs, 2014).

According to Sapriel (2003), smouldering crises are developing and non-event based crises, which are often initiated by management misbehavior or neglect. Lehtonen (2007) states that a boycott of Arla food products in the Middle East in 2005, which began because of cartoons of the prophet Mohammad published by the Danish newspaper Jyllands Post, is a good example of a smouldering crisis, because it took four months after the cartoons were published for the boycott to start. A key to effective crisis communication is to recognize a smouldering crisis well before its outbreak.

The old pattern in crisis communication was to focus on the perspective of the receiver instead of using a sender-oriented perspective (Coombs \& Holladay, 2012, p. 280). Early studies assumed that the organization's own perspective and perception of a crisis is "the truth", and messages sent based on that "truth" have to satisfy stakeholders. Now it is acknowledged that stakeholders' perceptions can determine whether a situation becomes a crisis for an organization or not (Gilpin \& Murphy, 2008, p. 14). In other words, a crisis is a perception and, ultimately, public perception is reality (Brown \& White, 2011, p. 76).

One of the factors affecting stakeholders' opinions is the level of responsibility they perceive an organization has for the crisis. Situational Crisis Communication Theory (SCCT) represents the social psychological orientation of crisis communication research, which focuses on situational and contextual aspects of crises (Frandsen \& Johansen, 2010, p. 427), developed to help organizations to minimize reputational damage as a result of a crisis (Coombs, 2004, 2007). The theory indicates that there is a connection between crisis attributions - how responsible the organization is seen for a crisis by stakeholders - and the communication strategy chosen. The history of the organization also affects people's interpretations (Coombs, 2007).

Attention has shifted from stakeholders and strict guidelines towards a multivocal and complex paradigm of crisis communication in recent years. Crises are actually complex situations, which are hard to predict and manage just by following how to do guidelines (Gilpin \& Murphy, 2008) or reading lists of best practices. 
Moreover, organization-stakeholder relations are not the only factor determining crisis communication, but there are multiple actors contributing to it (Schultz \& Raupp, 2010, p. 112). Fransen and Johansen (2010) call it the rhetorical arena, which opens up because of a crisis. In this arena, various actors are communicating, reframing the issue in the context of the outbreak of the crisis.

The theory of the rhetorical arena is not a public sphere model. It covers also semi-public (networks) and private (inside of organizations) areas, which for example are missing in the concept of an "issues arena" introduced by Luoma-aho and Vos (2010). They define an issues arena as "places of interaction where an issue is discussed by stakeholders and organizations" (Luoma-aho \& Vos, 2010, p. 4). The rhetorical arena can also open up long before a crisis, especially in the case of socalled smouldering crises. Moreover, the arena can stay open and cause a new crisis after the first one (Frandsen \& Johansen, 2010, p. 432).

\section{DEFINING ISSUES AND INITIATING CRISES IN SOCIAL MEDIA}

By definition, the social media means:

[...] web-based services that allow individuals to 1) construct a public or semi-public profile within the bounded system, 2) articulate a list of other users with whom they share a connection, and 3) view and traverse their list of connections and those made by others within the system. (Boyd \& Ellison, 2007, p. 211)

According to Kaplan and Haenlein (see Table 1), the social media platforms or applications can be classified by two dimensions; the level of self-disclosure or selfpresentation and the level of social presence and media richness.

The most important communication transformation in recent years has been the shift of mass communication to individual mass communication. The process of interactive communication that can potentially reach a mass audience, but in which the production of the message is self-generated, the retrieval of messages is self-directed, and the reception and remixing of content from electronic communication networks is self-selected (Castells, 2013, p. 29).

Table 1. Classification of social media

\begin{tabular}{|l|l|l|l|l|}
\cline { 2 - 5 } \multicolumn{2}{l|}{} & \multicolumn{3}{c|}{ Social presence/Media richness } \\
\cline { 2 - 5 } \multicolumn{2}{l|}{} & Low & \multicolumn{1}{c|}{ Medium } & \multicolumn{1}{c|}{ High } \\
\hline \multirow{2}{*}{$\begin{array}{l}\text { Self presentation/ } \\
\text { Self-disclosure }\end{array}$} & High & Blogs & $\begin{array}{l}\text { Social networking } \\
\text { sites (e.g., Facebook) }\end{array}$ & $\begin{array}{l}\text { Virtual social worlds } \\
\text { (e.g., Second Life) }\end{array}$ \\
\cline { 2 - 5 } & Lollaborative projects & $\begin{array}{l}\text { Content communi- } \\
\text { ties (e.g., YouTube) }\end{array}$ & $\begin{array}{l}\text { Virtual game worlds } \\
\text { (e.g., World of } \\
\text { Warcraft) }\end{array}$ \\
\hline
\end{tabular}

Source: Kaplan \& Haenlein (2010, p. 62). 
According to the model of the rhetorical arena, social media applications can be seen as semi-public channels where crisis messages are moving and where a journalist can move them to the public arena by publishing them in the mass media. Social media offers different stakeholders and actors of society an opportunity to express their perceptions and interpretations of the crisis. Social media is said to have an increasing role as social constructor of crises, but it is also an arena for corporations for their counter-actions (Schultz et al., 2011, p. 20). Publics assign a higher level of credibility in some cases to social media coverage than to traditional mass media crisis coverage (Procopio \& Procopio, 2007; Sweetser \& Metzgar, 2007). However, the real importance of social media in crisis communication remains vague (Liu et al., 2011, pp. 350-351).

Most social media content does not reach the public at the scale of traditional media, and consists of fragmented discussions or groups (Rasmussen, 2008) who gather around an issue or a topic which they perceive as interesting and worth of activity. However, organizations have to be ready for surprising actions initiated by sometimes emotional stakeholders (Luoma-aho \& Vos, 2010).

Freeman (1984) defines stakeholders as groups with something at stake in the relations with an organization, and they are groups which are necessary for an organization's survival. An organization's strategic goal is to meet the expectations stakeholders have (Luoma-aho, 2008, p. 81). For organizations, monitoring of social media is a potential way to get information on what stakeholders (Coombs \& Holladay, 2010, p. 280) think about the organization and try to understand their perceptions. Social media can be seen also as a new tool for relationship building, which is seen one of the core functions of public relations (Veil et al., 2011, p. 113).

\section{CITIZENS AS CRISIS COMMUNICATORS}

Social media has an increasing impact on crisis communication, because ordinary people can participate in crisis framing (van der Meer \& Verhoeven, 2013). However, traditional media still has the power to frame issues and crises. The daily selection of news reported by journalists affects people's perceptions (Carroll \& McCombs, 2003). Media offers information about a crisis and people form their opinions and analyse the cause and responsibility issues based on that information (An \& Gower, 2009). The media also builds agendas, which will later also become the agendas for the public and targets of interest (Carroll \& McCombs, 2003). Normally crisis frames which are presented in mass media are the ones stakeholders will experience and adopt. An exception is a crisis which happens mostly online. In those cases people who are writing crisis-related information online are simultaneously framing it (Coombs, 2007, p. 171). Van der Meer and Verhoeven (2013) suggest that people base crisis frames on personal speculation before the news media is able to provide extended coverage, at which point the social media frames 
align with news media frames. An explanation for this is that people still trust news media more and therefore they rather share news from online newspapers than information from blogs or Twitter (Utz et al., 2013).

Although mass media is still the main information provider and agenda builder, social media offers the possibility for ordinary citizens to raise issues and frame them from their own perspective. The issue is not only an existing question, but a subject which is perceived as a problem by multiple people (Crable \& Vibbert, 1985). Boycotts, for example, are a good example of ordinary citizens using their possibility to influence an outcome. Hunter et al. (2008) call the definition of meanings of a crisis as a power struggle. If activists manage to win the struggle, they can harm not only an organization's reputation but also cause big financial losses, similar to what happened to Danone SA in 2001 with its biscuit division (Hunter et al., 2008).

According to Crable and Vibbert, "issue management can permit an organization, with no actual authority, to influence public policy" $(1985$, p. 4). When applying this to boycotts, the efforts to promote a boycott can be viewed as issues management by a group of people, who do not have actual authority, but who can influence, for example, companies' policies and decisions. If a boycott is a success, it can be explained with the criteria for effective issues management.

What issues come to the media's attention, and who initially defines the issue often also steers the discussion (Crable \& Vibbert, 1988). This definitional hegemony, as Dionisopoulos and Crable (1988) call it, means that framing the narrative over an issue can also influence the outcome of the discussion.

The following research questions were asked for this article:

RQ1. Who defined the crisis narrative?

RQ2. How was the definition reached?

RQ3. How did the defined narrative affect the resolution of the crisis?

\section{METHODOLOGY AND EMPIRICAL DATA}

During the study, press releases and news articles published between the period of March 19-April 15, 2010, were examined, which covered the time span of the initiation of the crisis and its resolution. The material included seven official press releases from Rimi, and 31 news articles published by Postimees, Estonia's biggest daily newspaper, the weekly newspaper Eesti Ekspress, and the regional news wire agency, the Baltic News Service (BNS), representing everything released by the company and published by the most widely read mass media sources in Estonia. They were examined by using a qualitative, open text analysis technique to categorize its support for a boycott or criticism of a stakeholder. In April 2010, the marketing manager of the Rimi supermarket chain was interviewed as well in order to better establish the organization's perceptions of how the crisis unfolded. Moreover, more than 70 public posts made in the Facebook protest forum and 
the commenting forums of the mainstream media sources were analyzed in the study.

The Rimi supermarket chain in Estonia issued a press release (2010a) on March 19, 2010 , in which the organization announced they would no longer use meat produced in Estonia for products sold under Rimi's brand name. The explanation for the decision in the release was that the move would increase the assortment and quality of meat selection. The marketing manager of the multinational company, Rimi Baltic, also noted in the release that there were ongoing negotiations with Estonian producers, however no agreements had been reached at that time. In the press release, the marketing manager said:

Local (Estonian) meat factories obviously don't like the idea of having to compete with Rimi's own branded meat products. However, everyone can look at this from two angles, and either protest in spite of the changes, or on the contrary - begin selling meat under the Rimi brand name in Estonia, Latvia and Lithuania, as well as capture the opportunity to export meat to other supermarkets in central and eastern Europe that belong to the same group as Rimi. (Rimi, 2010a)

The Estonian mass media, as well as the public, paid little attention to the news release at the time. Two weeks passed before the public began to discuss and interpret the contents of the message sent by the supermarket chain. The initial message, extending the selection of Rimi's own-brand product and a more diverse assortment for the buyer, had now in the public's mind formed a new narrative - Rimi no longer sells Estonian meat in Estonia. The group "Boycott Rimi - Support the Estonian producer" was formed on April 9 on Facebook as a citizens' initiative (Boikott RIMI-le, 2010). Four days after the group's page was established, it had more than 4,000 followers, a larger number than Rimi's official Facebook page. At this point, the topic became a focus of public discussion in mainstream media outlets. The protest Facebook group became a forum for Estonian consumers' opinions and a shaper of attitudes by defining the dimensions and scope of what would become a crisis of public relations for Rimi.

The creation of the Facebook group was a pure citizen initiative. People expressed their indignation and, at the same time, used it to mobilize against the foreign-owned supermarket chain. Rimi announced four days after the creation of the group that they had underestimated Estonian consumers and Estonian meat under the Rimi label would be brought back to stores.

\section{RESULTS: PRESS RELEASES, SOCIAL MEDIA REACTION AND MEDIA COVERAGE}

Rimi's first press release, published on March 19, stated that Rimi was going to sell only imported meat under its own brand. The decision was made because the supermarket chain said it wanted to offer a standard of quality and a bigger product variety under its label. At the same time the retailer stated that negotiations with Estonian meat producers were still ongoing: 
We have not reached an agreement yet, but we wish to get the agreement fast ... We don't want to say no to Estonian meat ... but the amount of meat offered to the market is relatively small. Beef production is marginal in Estonia. (Evely Mägioja, marketing and communication manager of Rimi)

Some politicians and representatives of meat producers expressed their disappointment towards Rimi's decision in the mass media. Then it took almost three weeks before consumers activated social media and blamed Rimi for seemingly shuffling Estonian meat producers to the side. News media attention in Estonia exploded.

Of Rimi's seven press releases during the crisis, all but one had the same style. The first press release was clearly a transactional forwarding of the company's decision. The remaining six defended the original decision. Rimi reiterated that they did not want to stop selling Estonian meat completely, and that they were negotiating with Estonian meat producers. Estonian Rimi CEO Christer Östholm was cited as the spokesperson in all of the releases. One PR release concentrated on refuting statements, which was published in one really critical news article.

The media picked on one main idea from the release, "Rimi stops selling Estonian meat under its own Rimi product brand" and framed it as "Rimi is not selling Estonian meat anymore". Thus, the problem evolved from the fact that the Estonian media had omitted an important concept from the press release - "own product brand". This was the key phrase in Rimi's press release, but in mass media references and social media opinions the term was not given real importance. Most likely journalists saw this nuance unimportant in rephrasing Rimi's press release for the Estonian public.

The term "own product brand" also did not attract the attention of the customers who were gathering in the social media, because by that point people online spoke in emotional terms in comments, and wanted to organize a boycott against the supermarket chain. One long article published in the biggest Estonian weekly newspaper, Eesti Ekspress, on April 15 collected only critical comments towards the organization. A customer backlash began due to a feeling of insult at the apparent disrespect shown to domestic meat sellers by Rimi. The message was interpreted and media texts were based on only a selected part of the press release without additional comments from Rimi's representatives:

I was quite shocked at what I heard on the morning television today. From now on I try to use Prisma stores. (Rimi boycott supporter 1, April 15, 2010, 10:08 a.m.)

Svennson (referring to Swedish CEO of Rimi, Christer Östholm) should have been shown his place and he should understand that Estonians are the masters on their own land. (Rimi boycott supporter 2, April 15, 2010, 10:12 a.m.)

After the outbreak of the crisis, Rimi's defensive statements did not move public opinion. During the analysis it became obvious that the supermarket chain did not understand how its word choice had originally been perceived: 
Rimi announces that it will start to sell only imported meat under Rimi's own brand, because of quality and product variety issues. (Rimi press release, March 19, 2010)

Rimi is categorically rejecting the claim that Rimi considered the quality of Estonian raw meat low or insufficient. Rimi has not given such an assessment and such a reason has in no way influenced the selection of Rimi's meat products. (Rimi press release, April 12, 2010)

News articles published in the mass media were all negative in tone and critical of Rimi's announcement. News organizations concentrated on the negative effects of the company's decision for Estonia, including comments of representatives from the Estonian Agriculture and Chamber of Commerce, the Association of Estonian Meat Producers, the Union of Estonian Agriculture, and the Estonian University of Life Sciences. Various journalists also wrote opinion articles and reported the popularity of the Rimi boycott page in Facebook. Other grocery store chains explained their meat purchasing policy, stating that the majority of the meat they sold was produced in Estonia. Thus it is clear that articles were one-sided; Rimi's statements and counterarguments were not included. That pattern continued throughout the crisis.

Rimi's communication style was contradictory. Three days after the huge media attention and establishment of the Facebook boycott group (April 9), the supermarket chain announced their decision to bring Estonian meat back to its shops. On April 12, the Estonian CEO apologized and admitted that they had made a mistake, and had wrongly interpreted Estonian consumers' wishes. At the same time Rimi announced a temporary 20 percent price decrease on meat and other selected products.

On April 15, however, the company's communication style was once again defensive, even after backing off its initial position:

\footnotetext{
Rimi Eesti Food finds it regrettable that in his (April 15) article published in Eesti Ekspress, Martin Vilen, a specialist of the Estonian Agriculture and Chamber of Commerce, has accused Rimi of different "sins" without even asking for comments to any accusations... The given case is a onesided attack against Rimi and because of the author has not once turned to Rimi to explain the real situation, then the article contains numerous false statements and ignorance. (Rimi press release, April 15, 2010)
}

Significantly, after the reaction of the customers through social media, Rimi initially did not offer any pushback. An interview later conducted with the marketing manager of Rimi explained the reason for this was due to the individual being on vacation outside Estonia when the crisis started. There were no public comments from other managers at Rimi, either.

The mass media began to cite Facebook and the perspectives of the mass media was being drawn from social media sources. The leading anti-Rimi speakers in the mass media coverage were social media activists.

The active anti-Rimi campaign in social media lasted for about a month. During that time the initiative was in Facebook while the mass media cited and re- 
ferred to social media. However, the passive behavior at the customer level lasted even longer.

In the meat conflict context, customers who were active in social media were also judgmental about the sales practices of Rimi, and looked for situations in their stores where they could be critical of the organization. For example, in the case of some products, the sale price listed on the label was more than the normal price. All possible and impossible aspects were made public and by commenting on these, the social media community kept up its fighting spirit, for example:

Have you seen anything like this? Send a photo to rahvahaal@delfi.ee or use a "Rahva hääl" (Vox Populi) template, which you find on the left side of the website. (Delfi, April 14, 2010)

A couple of days after the formation of the Facebook group, Rimi began issuing statements. Rimi's marketing manager posted on the Facebook group to apologize in public and explain the company's attitudes towards the quality of Estonian meat and other customer-related issues:

\begin{abstract}
Rimi also wants to thank Estonians who were active in expressing their opinion. We admit that we have underestimated the interest of Estonian consumers in local products [...]. We also want to apologise for the regrettable and misleading message as if we would not consider Estonian meat's quality high enough. (Evelin Mägioja, marketing and communication manager of Rimi, April 12, 2010)
\end{abstract}

But instead of having a calming effect, the apology actually intensified the conflict. The comments of the marketing manager on the Facebook boycott page aroused anger, and comments from the public became emotionally sharp and, in some cases, personally insulting. However, on April 13, the initiator of the activist group expressed her excitement at the amount of new members of the boycott group by declaring victory:

Today has been rapturous. First of all it is the day of victory, because Rimi admitted its mistake and we are very glad about that ... today another 400 people have joined the group! I would have never believed that this would get so big and interesting. (Kati Varblane, the initiator of the Facebook activist group, April 13, 2010)

Various commentators on Facebook and forums of mass media channels were extremely indignant and people were mobilized relatively quickly in the boycott of Rimi supermarkets. On the Facebook group it was agreed that as a protest, people would no longer make purchases in the outlets of this supermarket chain.

\title{
DISCUSSION
}

In the analysis of news media articles, press releases and online comments, the study tried to determine who defined the crisis narrative and controlled the discussion (establishing "definitional hegemony" regarding the topic), and how the nar- 
rative affected the resolution of the crisis. The analysis indicates Estonian consumers as well as the news media defined the problem, set the narrative of the crisis, and therefore controlled the discussion throughout the entire episode. This strong control, the negative attention initiated in social media, and the reactive position in which Rimi found itself, forced it to cancel its original decision.

According to Crable and Vibbert (1985), the one whose definition enters the media first is able to lead the discussion by defining the narrative from the outset. In this case Rimi entered the media arena first (first press release on March 19), but used relatively unclear language, which was misinterpreted by journalists, either deliberately or by accident.

Three weeks later the topic was covered widely in the news media, which at the same time further defined definition of the crisis. Good issues management is based on early reactions, or even dynamic activities when a company tries to anticipate changes and initiate the topic of public discussion (Crable \& Vibbert, 1985). Rimi neglected this chance and therefore the crisis was a surprise for the company management. According to Sapriel (2003), smouldering crises develop which are often initiated by management misbehavior or neglect. It can be stated that Rimi did not perceive the topic as a smouldering crisis and therefore did not also execute any mitigative actions. Most probably the company could have predicted the crisis before its outbreak, if the media environment was more effectively monitored. As van der Meer \& Verhoeven (2013) write, ordinary citizens used their freedom to define a crisis by using social media, or more precisely in this case, Facebook.

After being challenged in social media (Shirky, 2011) Rimi choose a strategy of apology and defensiveness in its communications, which was reflected in the media as untrustworthy. People interpreted it as a deliberate decision to put pressure on Estonian meat producers, which led the company to climb down from its decision. However, nobody believed the apology, because Rimi's communications tried to justify its choice and blame its critics. After the first press release, the company could have monitored the environment and noticed the dissatisfaction of its customers. As Crable and Vibbert (1985) state, an issue needs time for development from a potential issue to a current one.

Rimi did not make significant changes in its sales tactics when the crisis emerged. The company at first did not attempt a reconciliation with the critical community of social media that was organizing the boycott, and the reaction of Estonian consumer stakeholders was driven by their perception of the organization's perceived strong crisis responsibility. According to SCCT theory, in the crisis of strongly perceived responsibility the strategy chosen should be apology or compensation, not denial or defensiveness (Coombs, 2007; Coombs \& Holladay, 2004).

When scrutinizing the crisis via the model of the "rhetorical arena" introduced by Frandsen and Johansen (2010), we can map the different actors. There were 
a multitude of actors in this particular arena, but there were no stakeholders defending Rimi. The supermarket chain tried to defend itself through its public relations arm alone against the news media, social media attention and public blame. The company did not succeed in changing the definition of the crisis as firstly defined by social media and then the news media ("Rimi will no longer sell Estonian meat") and therefore had to backtrack quickly and bring Estonian meat back to its stores. That happened only three days after the initial outbreak of the crisis. Other actors of the arena were active citizens, representatives of Estonian meat producers, politicians and journalists.

An unwise choice of words put Rimi in a bad position. Rimi apologized, but invalidated this apology by simultaneously blaming the media coverage as different from its real intent, thus its messaging strategy was contradictory. By offering lower prices, Rimi obviously wanted to attract customers back to its shops, a plan of action that can be seen as a form of compensation by SCCT theory. However, consumers used it as a tool to publicly punish the company and later started to collect evidence of false discounts.

Rimi's sales tactics were widely scrutinized, and its mistakes were searched for in all areas. The observations were made public in social media, and these received sensitive and emotional responses. Social media had become an active and critical "guard dog" in this case, making it a good example of secondary crisis communication by consumers. Officially, Rimi noted a decrease of turnover of 12.5 percent for the first half of 2010 in the Baltic countries of Estonia, Latvia and Lithuania (2010b). No comment was made on this decrease; it was merely verified as such.

Rimi seemed to underestimate the importance of domestic meat for Estonians and scrutinized the situation from an organization's point of view. Rimi did not understand that crises are socially constructed processes, and it led to serious shortcomings in internal sense-making and crisis communication.

Thus, based on analysis of this case, the Rimi supermarket chain's official press release (2010a) contained three problematic crisis communication issues:

1. A public organization-oriented communication with contradictory messages and insufficient formulation of the public message.

2. A lack of issues management and ignorance (emotional, emphatic) of an international conglomerate towards the attitudes and opinions of a relatively small consumer base.

3. An ignorance of the integrative power of social media in mobilizing a crowd.

In the meat-selling case of Rimi all three aspects were present simultaneously and created a situation where Rimi supermarkets lost customers. Due to the opportunities of social media, a wrongly formulated message very quickly started influencing Rimi's customer relations, reputation and also indirectly through this, its cash flow. 


\section{CONCLUSIONS}

The 2010 boycott case of Rimi combines several elements of a modern crisis and its management. First, there was a move by stakeholders to punish the organization for its decision, and the move toward a consumer boycott of the chain was driven entirely at first by social media activism. Second, the crisis was precipitated by the public relations releases by the organization, and the backlash of consumer stakeholders was amplified by the traditional mass media, who took their story cues from what was being said in social media. Third, there was a misreading by Rimi's stakeholders on what the actual consequences of the move away from Rimi-labeled Estonian meat implied in real terms.

However, Rimi did not show enough appreciation for how their message, ambiguously articulated at first, could feed impulses that could inflame its stakeholders. Once the narrative that Estonian meat itself would not be sold by Rimi, instead of just under Rimi's brand, the company found it impossible - partially due to its ill-formulated attempts at crisis management communication - to reverse public opinion. In the modern media context, an organization in a similar situation may only get one opportunity to define an issue before it is defined for them by others.

This study shows the connection between issues management, definition hegemony and crisis responsibility, and how wide public pressure can cause changes in an organization's policy. It also indicates that ordinary people have the power to influence, although they do not have the power to make an organization's decision themselves. The study also suggests that social media can easily become the initiator of movements and the creator of reputations. But one must not underestimate the news media's role, either. Secondly, organizations have to be extremely careful in formulating their messages, because different factors can create different interpretations. When trying to direct the flow of communication, it is necessary to be constantly aware of the possible simultaneous influence of social, cultural, economic and political factors emphasized by Frandsen and Johansen (2010). The Rimi case showed that cultural misinterpretations can sabotage a company's reputation and also cause a decline in turnover.

In the era of fast communication both in news media and social media, it is important to understand that who defines the issue often also steers the resulting discussion (Crable \& Vibbert, 1985). After the outbreak of a crisis, it is extremely challenging to change how it is initially defined. This "definitional hegemony", as Dionisopoulos and Crable (1988) call it, can determine the solution of the crisis, which happened in Rimi's case when the company backtracked on its plans after three days of media attention.

In communication, it is most important for the organization to have a careful overview of the operational environment and a clear understanding of its connection with communication. It is impossible to perform successful public communications if the contexts of culture and values is not taking into account while making 
decisions and communication about them. In this particular case study of Estonia, the crisis occurred where the decision of the company seemingly impinged on the honor of a small nation-state through the goods their meat producers brought to the market, there was no indication that the forces and arguments operating in the rhetorical arena of public opinion were unique because of its location, or would have differed given a change of venue. However, further examination of how cultural values can impact the development of a crisis is a subject that is much needed in the field of crisis scholarship.

The traditional organization-centered worldview is no longer valid in the contemporary media environment. As Brown \& White (2011, p. 76) put it, public perception is the ultimate reality in a crisis. In countries with highly developed IT levels, a crisis can evolve in environments that at first seem harmless. Therefore all social media communities need to be monitored carefully in order to be aware of the opinions and attitudes of the stakeholders. In addition to disseminating information using social media, there is also the opportunity for secondary crisis communication and effective mobilization of the crowd, irrespective of the topic in the social media realm.

The challenges that social media, fast information flow, and multicultural settings represent to organizations and their public relations professionals call for more detailed and systematic analyses and study of public discussions, the role of definition hegemony and its effect on crisis solutions, as well as other aspects which are altering message interpretation.

\section{REFERENCES}

An, S.-K., Gower, K.K. (2009). How do the news media frame crises? A content analysis of crises news coverage. Public Relations Review, 35 (1), pp. 107-112.

Boikott RIMI-le [Boycott Rimi]. Facebook group. Retrieved February 17, 2013 from http://www.facebook.com/pages/Boikott-RIMI-le/116296508387461.

Boyd, D.M., Ellison, N.B. (2007). Social network sites: Definitions, history and scholarships. Journal of Computer Mediated Communication, 13 (1), pp. 210-230.

Brown, K.A., White, C.L. (2011). Organization-public relationships and crisis response strategies: Impact on attribution of responsibility. Journal of Public Relations Research, 23 (1), pp. 75-92.

Capozzi, L., Zipfel, L. (2012). The conversation age: The opportunity for public relations. Corporate Communications: An International Journal, 17 (3), pp. 336-349.

Carroll, C.E., McCombs, M. (2003). Agenda-setting effects of business news on the public's images and opinions about major corporations. Corporate Reputation Review, 6 (1), pp. 36-46.

Castells, M. (2013). Communication Power (2nd ed.). New York: Oxford University Press.

Cheng, Y., Liang, J.W., Leung, L. (2014). Social network service use on mobile devices: An examination of gratifications, civic attitudes and civic engagement in China. New Media \& Society [SSCI].

Conway, T., Ward, M., Lewis, G., Bernhardt, A. (2007). Internet crisis potential: The importance of a strategic approach to marketing communications. Journal of Marketing Communications, 13 (3), pp. 213-228.

Coombs, W.T. (2006). Crisis management: A communicative approach. In: Botan, C.H., Hazelton, V. (eds.). Public Relations Theory II. Mahwah, NJ: Lawrence Erlbaum Associates, pp. 149-173. 
Coombs, W.T. (2007). Protecting organization reputations during a crisis: The development and application of situational crisis communication theory. Corporate Reputation Review, 10, pp. 163-176.

Coombs, W.T. (2014). Ongoing Crisis Communication. Planning, Managing, and Responding (4th ed.). Thousand Oaks, CA: Sage.

Coombs, W.T., Holladay, S.J. (2002). Helping crisis managers protect reputational assets: Initial tests of the situational crisis communication theory. Management Communication Quarterly, 16, pp. 165-186.

Coombs, W.T., Holladay, S.J. (2012). Amazon.com's Orwellian nightmare: Exploring apology in an online environment. Journal of Communication Management, 16 (3), pp. 280-295.

Coombs, W.T., Holladay, S.J. (2014). How publics react to crisis communication efforts. Journal of Communication Management, 18 (1), pp. 40-57.

Crable, R.E., Faulkner, M.M. (1988). The issue development graph: A tool for research and analysis. Central States Speech Journal, 39 (2), pp. 110-120.

Crable, R.E., Vibbert, S.L. (1985). Managing issues and influencing public policy. Public Relations Review, 11 (2), pp. 3-16.

Dionisopoulos, G.N., Crable, R.E. (1988). Definitional hegemony as a public relations strategy: The rhetoric of the nuclear power industry after Three Mile Island. Central State Speech Journal, 39 (2), pp. 134-145.

Frandsen, F., Johansen, W. (2010). Crisis communication, complexity, and the cartoon affair: A case study. In: Coombs, W.T., Holladay, S. (eds.). The Handbook of Crisis Communication. Malden, MA: Wiley-Blackwell.

Freeman, R.E. (1984). Strategic Management: A Stakeholder Approach. Boston: Pitman.

Gilpin, D.R., Murphy, P.J. (2008). Crisis Management in A Complex World. New York: Oxford University Press.

Haigh, M.M., Wigley, S. (2015). Examining the impact of negative, user-generated content on stakeholders. Corporate Communications: An International Journal, 20 (1), pp. 63-75.

Hunter, M.L., Le Menestrel, M., Bettignies de, H.-C. (2008). Beyond control: Crisis strategies and stakeholder media in the Danone boycott of 2001. Corporate Reputation Review, 11 (4), pp. 335 350.

Kaplan, A.M., Haenlein, M. (2010). Users of the world, unite! The challenges and opportunities of social media. Business Horizons, 53, pp. 59-68.

Lehtonen, J. (2007). Country image and consumer nationalism. Case Arla and the Mohammed cartoons episode. In: Schmidt, C.M., Neuendorff, D. (eds.). Sprache, Kultur und Zielgruppen. Bedingungsgrössen für die Kommunikatsiongestaltung in der Wirtschaft. Wiesbaden: Deutscher Universitäts-Verlag.

Liu, B.F., Austin, L., Jin, Y. (2011). How publics respond to crisis communication strategies: The interplay of information form and source. Public Relations Review, 37 (4), pp. 345-353.

Luoma-aho, V. (2008). Viha, rakkaus ja stakeholder-suhteet [Hate, love and stakeholder relations]. In: Aula, P. (eds.). Kivi vai katedraali. Organisaatioviestintä teoriasta käytäntöön [Stone or Cathedral. Organizational Communication From Theory to Practice]. Porvoo: Infor Oy, pp. 79-95.

Luoma-aho, V., Vos, M. (2010). Towards a more dynamic stakeholder model: Acknowledging multiple issue arenas. Corporate Communications: An International Journal, 15 (3), pp. 315-331.

Meer, van der, T., Verhoeven, P. (2013). Public framing organizational crisis situations: Social media versus news media. Public Relations Review, 39 (3), pp. 229-231.

Pang, A., Hassan, N.B.B.A., Chong, A.C.Y. (2014). Negotiating crisis in the social media environment. Corporate Communications: An International Journal, 19 (1), pp. 96-118.

Procopio, C.H., Procopio, S.T. (2007). Do you know what it means to miss New Orleans? Internet communication, geographic community, and social capital in crisis. Journal of Applied Communication Research, 35 (1), pp. 67-87. 
Rasmussen, T. (2008). Two faces of the public sphere. The significance of internet communication in public deliberation. Nordicom Review, 29 (2), pp. 73-83.

Riel van, C.B.M., Balmer, J.M.T. (1997). Corporate identity: The concept, its measurement and management. European Journal of Marketing, 31 (5), pp. 340-355.

Rimi press release. (2010a). Rimi is expanding choice of beef products in Estonian market. Retrieved April 21, 2011 from http://www.rimi.ee/uudised/515-view-1900.html.

Rimi press release (2010b). Turnover of Rimi Baltic Group, first semester of 2010. Retrieved April 21, 2011 from http://www.rimi.ee/uudised/1005-view-1954.html.

Rimi Baltic (2014). Expansion and Strong Profitability. ICA Gruppen Annual Report 2014. Retrieved April 20, 2015 from http://www.icagruppen.se/en/rapportportal/annual-report-2014/\#!\#icagruppens-operations_rimi-baltic.

Sapriel, C. (2003). Effective crisis management: Tools and best practices for the new millenium. Journal of Communication Management, 7 (4), pp. 1-8.

Schultz, F., Raupp, J. (2010). The social construction of crises in governmental and corporate communications: An inter-organizational and inter-systemic analysis. Public Relations Review, 36, pp. 112-119.

Schultz, F., Utz, S., Göritz, A. (2011). Is the medium the message? Perceptions of and reactions to crisis communication via twitter, blogs and traditional media. Public Relations Review, 37, pp. 20-27.

Shirky, C. (2011). The political power of social media: Technology, the public sphere and political change. Foreign Affairs, 90 (1), pp. 28-41.

Siah, J., Bansal, M., Pang, A. (2010). New media: A new medium in escalating crises? Corporate Communications: An International Journal, 15 (2), pp. 143-155.

Sweetser, K.D., Metzgar, E. (2007). Communicating during crisis: Use of blogs as a relationship management tool. Public Relations Review, 33 (3), pp. 340-342.

Tirkkonen, P., Luoma-aho, V. (2011). Online authority communication during an epidemic: A Finnish example. Public Relations Review, 37 (2), pp. 172-174.

Ulmer, R.R., Sellnow, T.L., Seeger, M.W. (2011). Effective Crisis Communication. Moving From Crisis to Opportunity (2nd ed.). Sage Thousands Oaks: California.

Utz, S., Schultz, F., Glocka, S. (2013). Crisis communication online: How medium, crisis type and emotions affected public relations in the Fukushima Daiichi nuclear disaster. Public Relations Review, 39, pp. 40-46.

Veil, S.R., Buehner, T., Palenchar, M.J. (2011). A work-in-process literature review: Incorporating social media in risk and crisis communication. Journal of Contingencies and Crisis Management, 19 (2), pp. 110-122.

Verhoeven, P., Tench, R., Zerfass, A., Moreno, A., Verčič, D. (2014). Crisis? What crisis? How European professionals handle crisis and crisis communication. Public Relations Review, 40 (1), pp. 107-109. 